\title{
An exploration of the youth's perception toward social entrepreneurship development: Evidence from Bangladesh
}

\author{
Dewan Mehrab Ashrafi ${ }^{1}$, Md Atiqur Rahman Sarker ${ }^{2 *}$, Junaidah Binti Hashim ${ }^{3}$, Ahasanul \\ Haque $^{4}$, Fatima Kanis Nayan ${ }^{5}$ \\ ${ }^{1}$ School of Business Administration, East Delta University, Chittagong, Bangladesh \\ ${ }^{2}$ Department of Business Administration, Kulliyyah of Economics and Management \\ Sciences, International Islamic University Malaysia, Selangor, Malaysia \\ ${ }^{3}$ Department of Business Administration, Kulliyyah of Economics and Management \\ Sciences, International Islamic University Malaysia, Selangor, Malaysia \\ ${ }^{4}$ Department of Business Administration, Kulliyyah of Economics and Management \\ Sciences, International Islamic University Malaysia, Selangor, Malaysia \\ ${ }^{5}$ School of Business \& Economics, North South University, Dhaka, Bangladesh \\ *Corresponding Author(s) Email: sarker.limon@gmail.com
}

\section{ABSTRACT}

A plethora of researchers has dominantly kept their focal point on the concept of social entrepreneurship and its economic development and sustainable aspect, but very few studies have been carried out which solely emphasized the youth and social entrepreneurship in Bangladesh. This study aims to explore the factors associated with the perception development of social entrepreneurship intention among business school graduates in Bangladesh. Primary data has been collected by using a structured questionnaire on 350 respondents and analyzed by using Spearman correlation. This study revealed most of the young graduates chose to participate in social entrepreneurship since it allows them to be independent and help to fulfill their social spirit. They also perceived that social entrepreneurship as a respectable and noble career. Interestingly, they also considered that job as risky and seems like take the advantage of other difficulties or poverty. They are also do not get family support to do social business because they perceived that social entrepreneurship is only for people who cannot get the desired job.

Keywords: Social Entrepreneurship; Society Perception; Government Obstacles; Barrier; Motivation
JEL Code:

M21, N85, O15, P21

DOI:

10.31106/jema.v17i1.5539

Article History:

Received 2020-01-26

Reviewed 2020-02-20

Revised 2020-03-05

Accepted 2020-03-05

Licensed:

CC-BY 


\section{Introduction}

The concept of social entrepreneurship has made tremendous breakthroughs worldwide. The prevalent concept of entrepreneurship, in the setting of business ventures, has been increasingly used for social problem solving set up (Dees \& Anderson, 2003). When the Grameen Bank of Bangladesh won the Nobel Prize for Peace, it has been considered by many as a turning point in the global acknowledgment of social entrepreneurship (Martin \& Osberg, 2007). Entrepreneurship can prove to be an effective instrument for economic value creation and simultaneously, a means to deal with various social issues (Tiwari et al., 2017). According to Weaver (2018), social entrepreneurship facilitates social capacity building and argues that the capacity building approach leads to social value creation. A social entrepreneur is an individual who comes up with innovative solutions to society's most pressing and crucial social problems. Maas \& Grieco (2017) hold the view that social entrepreneurship is an effective vehicle that not only drives but also tackles the societal problems innovatively. Furthermore, Lubberink et al. (2018) concurs with Maas \& Grieco (2017) that social entrepreneurs come up with creative and innovative solutions to complicated and crucial societal problems. According to Lubberink et al. (2018), the individuals who started these organizations wanted them to be financially self-sustaining while serving an environmental or social purpose. Social entrepreneurs can apply patternbreaking thoughts to address important problems of society. According to Haugh (2007), social entrepreneurship with the simultaneous pursuit of economic, societal, and environmental goals by enterprising ventures, has gradually found a spot along the world's stage as a human reaction to social and environmental problems. Instead of personal and shareholder's wealth gain, the underlying cause of social entrepreneurship is to create social value, and that action is characterized by innovation, or the institution of something new rather than simply the return of existing enterprises or practices. According to Mueller et al. (2015), the government acknowledges its problem-solving nature and stimulates social entrepreneurship due to its innovation. Phillips et al. (2015) analyzed the literature to discover the association between social innovation and social entrepreneurship and concluded that both of them aim to quest after solving societal problems. It can be said that the key concepts of social entrepreneurship are innovation, market orientation, and systems change and, their prime objective is to create sustainable systems change. According to Banodia \& Dubey (2017), it is spreading rapidly and catching the attention of the market, society, and government. 
According to Catford (1998), social and economic entrepreneurs share identical visions and opportunities and the same power to convince and empower others to help them turn these visions into reality. However, the troubles of finding out efficacious and sustainable answers to myriad social problems are crucial, and solutions may necessitate many of the factors related to successful business innovation of the constellation of troubles linked to long-term impoverishment; such problems often require fundamental shifts in economic, social, and political systems (Alvord et al., 2004). This study aims to elucidate the problems, prospects and the significant factors that motivate young graduates to engage in social entrepreneurship in Bangladesh since the unemployment rate is increasing and the youth should take entrepreneurial initiatives for several social problems such as poverty due to natural calamities, deforestation, pollutions for unplanned industrialization, etc. Particular attention has been given in this study to identify the issues that affect the perception of social entrepreneurship among young graduates in Bangladesh.

\section{Literature Review}

Sassmannshausen \& Volkmann (2018) mentioned that the discussion of social entrepreneurship is now progressed at a mature state due to its impacts and considers that earlier researches on social entrepreneurship mainly kept the conceptualization as well defined as the focal point. According to Tiwari et al. (2017a), the roots of social entrepreneurship exist mainly in the evolution of the private sector. One of the growing discussions in the field of social entrepreneurship is how to define and differentiate a social enterprise from a profit-seeking enterprise (Lubberink et al., 2018). Social entrepreneurship generally refers to the phenomenon of applying business expertise and market-based skills in the non-profit sector such as when non-profit-making organizations buildup innovative approaches to bring in income (Thompson, 2002). A social entrepreneur can be described as "someone who has created and led an organization, whether for-profit or not, that is aimed at catalyzing systematic social change through new ideas, products, services, methodologies and changes in attitude" (Thompson, 2002). However, the academic field of social entrepreneurship is gaining prominence (Lubberink et al., 2018). Smith-Hunter (2011) mentioned that the most important point of social entrepreneurship is social value creation. De Bruin \& Lewis (2015) argued that the social entrepreneurship context is diverse as well as complex. According to Tiwari et al. (2017b), social enterprises provide an ingenious idea towards providing commodities, services and earning opportunities to the economically weaker section of the society. They work in the community to help others and act as a change 
maker to create and sustain social value. Baporikar (2017) opined that social entrepreneurs are like business entrepreneurs. They also gain profit but their core focus is on society by addressing societal needs by solving problems.

Social entrepreneurs can be views as non-profit executives who pay increased attention to market forces without losing their mission. Thompson (2002) stated that social entrepreneurs might have the qualities and behaviors generally connected with business entrepreneurs, but they work in communities and are more concerned with caring and helping, than with getting money. The mission of social entrepreneurs is changing to help people's lives solving social problems. However, Waddock \& Steckler (2016) illustrated that only fifty percent of social entrepreneurs start to carry out their activity by having a clear vision. On the contrary, Lubberink et al. (2018) also opined that social entrepreneurship is a political phenomenon and the goal should be adjusted to the social problem. Nevertheless, they act as change agents in the social sector and adopt missions to create and sustain social value, employ in a process of continuous innovation, adaptation and act with courage without being defined by resources currently in hand. Carvalho (2017) pinpointed that social entrepreneurship creates value for society through innovation and this innovation leads to human, social and territorial development. Like business entrepreneurs, social entrepreneurs recognize and act upon opportunities to ameliorate systems, create solutions, and forge new approaches (Seelos \& Mair, 2005). Moreover, Alvord et al. (2004) revealed that initiatives based on movement-building focused on external relationships and have used the political targets as leverage to get transformational effects not only on political but also cultural circumstances. They also depicted that, social entrepreneurship mobilizes as well as builds assets which make it possible to leverage smaller investments to develop sustainable changes. They also opined that social entrepreneurship has the potential and capacity to reach millions of people by creating social transformation and having high transformational effects might be possible by having collaboration with many organizational arrangements.

However, in the study literature, social entrepreneurship is also a topic of debate. The idea of social entrepreneurship means different things to different people and researchers (Dees \& Elias, 1998). Some authors argue that it exists primarily in the non-profit sector to provide business expertise and market-based skills to help this sector become more efficient at delivering services (Thompson, 2002), while others define social entrepreneurship more widely, stating that social entrepreneurship can occur within the public, private or not-forprofit sectors. In essence, it's a hybrid model that involves both for-profit and not-for-profit 
activities. This idea suggests social entrepreneurship can take different forms, including innovative non-profit ventures and social purpose business ventures (Dees \& Elias, 1998). However, some gaps are still existent (Sassmannshausen \& Volkmann, 2018). It is critical to mention that, there is no unanimity about the definition of social entrepreneurship (Choi \& Majumdar, 2014). However, Newth \& Woods (2014) suggested that the establishment of the definition should be put forward to drive the entrepreneurial process and procedure that necessitates the development of opportunities and resource combination process. Nevertheless, it can be said that although it has many challenges, it serves as a powerful force because social entrepreneurship provides opportunities for creating social value (Baporikar, 2017).

The prevalent concept of entrepreneurship, in the setting of business ventures, has been increasingly used for social problem-solving settings (Dees \& Anderson, 2003). Social entrepreneurs are the people who have an innovative solution for the various social problems present in the society which have been neglected by different agencies (Banodia \& Dubey, 2017). The broad view of entrepreneurship presents the multidimensional nature of human beings (von Jacobi et al., 2017). Rather than personal, and shareholder's wealth gain, the underlying cause of social entrepreneurship is to create social value, and that action is characterized by innovation, or the institution of something new rather than simply the return of existing enterprises or practices. So, it can be deduced that the more the innovation will be, the more social entrepreneurship will advance (Phillips et al., 2015). Blok et al., (2015) suggested that stakeholder engagement is crucial and should be kept as a focal point for responsible innovation.

Smith-Hunter (2011) mentioned that the most important point of social entrepreneurship is social value creation. According to Thompson (2002), social entrepreneurs might have the behavior and qualities generally linked with business entrepreneurs, but they work in communities and are more focused on helping others than with getting money. The mission of social entrepreneurs is changing to help people's lives by solving social problems. Nevertheless, they act as change agents in the social sector and adopt missions to create and sustain social value, employ in a process of continuous learning and move forward boldly without being defined by resources currently in hand. Social entrepreneurship acts as a precursor to social transformation and it seeks to change the system of global capitalism (Newey, 2018). Von Jacobi et al. (2017) hold the view that social entrepreneurship is a potential driver for turbulent and transformational social changes because of its capacity to solve the problems that institutional status quo neglects. 
Like business entrepreneurs, social entrepreneurs identify and act upon opportunities to ameliorate systems, create solutions, and forge new approaches (Seelos \& Mair, 2005). Social entrepreneurs are unlike traditional ones in one essential point of view, which is the result of their activities. The success of traditional entrepreneurs is economic whereas social entrepreneurs might reach double success - economic and societal Smith-Hunter (2011). People develop their identities as individuals in the adolescence period when they start to explore broadening social relations, and interact independently with the wider community. The most leadership theorists believe that the skills crucial for effective leadership, including the ability to understand and communicate with others, are developed most deeply in adolescence and young adulthood. According to Davis (2002), "Engaging and involving young people in initiatives that they create not only makes them stakeholders of their immediate future but also their community's long-term well-being". For being a social entrepreneur, youth is a perfect time for developing and acquiring the required essential skills of teamwork, empathy, and leadership. Tiwari et al. (2017a) carried out a study with a sample of 230 university students in India to associate an individual's self-efficacy with the attitude towards becoming a social entrepreneur and intention to become social entrepreneurship and concluded that a person's self-efficacy is positively related to both attitude and intention of becoming social entrepreneurs. Chandra \& Shang (2017) explained that the combination of social skills and social position motivates an individual to take social entrepreneurship as a career. Important skill development programs including, public speaking, writing, planning, critical thinking, and group dynamics; youth social entrepreneurship also has strong potential to make a more involved and engaged citizen (Davis, 2002). Drayton (2006) argues "If young people do not grow up being powerful, causing change, and practicing, these three interlocked underlying skills, they will reach adulthood with a self-definition that does not include change-making and social skillset that largely precludes it. Just as one must develop strong emotional foundations in the first three years of life or suffer for a lifetime, young people must master and practice these social skills and the high art of being powerful in and through society while they are young". An opportunity for showing leadership should be provided to young people, a chance to create something at a very young age to understand this is something they can do; they can contribute to solving the world's problems (Davis, 2002). Youth social entrepreneurship delivers an opportunity for young people to develop, practice and exercise leadership by bringing changes in their communities. According to a study published by the United Nations Children's Fund, people who engaged themselves in 
the community before age 14 tend to be involved more in the community as adults. The youth who have had these opportunities are significantly more likely to stay devoted and active community members. Davis (2002) argued that if young people have the opportunity to learn by doing, they can be better equipped to positively impact their communities. Social entrepreneurs are not only marked by their input in producing and creating value but also have a big social impact in vulnerable groups and communities (Silva \& Poza, 2016). Banodia \& Dubey (2017) explained that social enterprises today are directed by a strong social mission and have all the potential and possibilities to ensure public welfare on a wide and large scale. Youth social entrepreneurship can be a dynamic and powerful strategy in recognizing that young people hold the capacity to address social problems. Through youth social entrepreneurship, ideas and energy of young people can contribute to the community building as they work for bringing up a social change by applying their leadership skills. However, the networks, supports, and opportunities will also facilitate their development in the future.

Between the 1980s and 1990s, field building organizations emerged that concentrated solely on social entrepreneurship. Public policy in various countries started to explore the possibilities of social entrepreneurship (Dees \& Anderson, 2003). However, according to Phillips et al. (2015), social entrepreneurship can act as a changing agent to solve myriad challenges of the society such as massive inequalities in education, high unemployment, housing, and the HIV pandemic, etc. Literature reveals that social entrepreneurs play a vital role in fighting social and economic problems in society by enabling economic opportunities and battling impoverishment. Social entrepreneurs are highly ambitious, solving social problems or effecting social change and they are committed to bringing a change in the society by being not only visionary but also a realist (Banodia \& Dubey, 2017). According to Martín \& Cuervo-Arango (2016), promoting entrepreneurial attitude is of paramount importance and education is one of the pivotal factors that influence an individual to pursue their social entrepreneurship project. Therefore, their good intentions overcome business realities. However, they have developed a model entitled "Pyramid of catalysts for entrepreneurship" which helps to apprehend the system by which the educational process impacts the quality or quantity of social entrepreneurship. On the other hand, social entrepreneurs also strive to work for the welfare of society by taking a mission to create and sustain social value by recognizing and unrelentingly pursuing new opportunities to serve that mission and poverty rates (Phillips et al., 2015) and alleviation of poverty cannot be ensured in a sustained way unless the poor people are empowered (Baporikar, 2017). Besides, social 
entrepreneurs can make important changes in the economy, and thus become agents of economic development and job and wealth creation that can ameliorate the welfare of the community (Wiklund et al., 2011). According to Sijabat (2015), lack of access to formal financial institutions is a big obstacle faced by the poor because most of them, engaging themselves with the informal sector. According to Newth \& Woods (2014) the lack of interest of banks to provide loans to social entrepreneurs was identified as one of the major barriers which hinder the growth and development of social entrepreneurship.

Therefore, efforts to encourage business activity in the informal sector should be emphasized to expand access to financial resources (Sijabat, 2015). Grameen Bank in Bangladesh is a perfect embodiment of the creation and expansion of access to finance for the poor. It also plays an important role in poverty reduction in Bangladesh by channeling loans to the destitute using schemes that are unlike those informal banking where loans are disbursed based on mutual trust, participation, accountability, and creativity instead of providing guarantee (Pervez et al., 2013). Grameen Bank has a crucial role in combating poverty and also in encouraging various economic activities and social advancement in Bangladesh. Future social entrepreneurs in Bangladesh has a bigger scope to come up with innovative and creative ideas to solve various challenges and problems of the society through their leadership skills to facilitate a change for a better tomorrow. Social entrepreneurs use ideas and make groundbreaking solutions to overcome social problems (von Jacobi et al., 2017). They utilize personal leadership skills and the capacity to solve problems that arise in particular communities or regions. According to Banodia \& Dubey (2017), social entrepreneurs may or may not earn a profit, maybe voluntary and work for the empowerment of the weaker section of the society.

In addition to that, social entrepreneurs create social values by exploiting innovation such as establish new activities or organizations (Pervez et al., 2013). Phillips et al. (2015) also suggested that the concept of social entrepreneurship can be advanced by focusing on social innovation. On the other hand, empowerment is a significant aspect of social entrepreneurship because social entrepreneurs have limited access to resources while addressing social problems (Sijabat, 2015). Besides, unemployment rates in Bangladesh are similar to other low-income countries in South Asia. However, among the younger age groups, unemployment tends to be concentrated. The income of daily wage labor is very low and poverty rates are higher. Sijabat (2015) argued that skill mismatch is the poor's greatest barrier in finding jobs. So the best possible way to help the poor is to create jobs and integrate 
the poor into available jobs outside the competitive labor market. Martin \& Osberg (2007) stated that social entrepreneurs emerge due to impoverishment, marginalization, and exclusion in society and some individuals take the initiative of battling social problems by using business principles. Social change in poor communities made by social entrepreneurs improves the quality of life, efficiency, and sustainability of social and economic growth (Popoviciu \& Popoviciu, 2011). As there is a very thin line existent between the role responsibilities and moral responsibilities, according to Stilgoe at al. (2013), a person needs to blur the lines between them. Therefore, the scope of social entrepreneurship has greater scope in countries like Bangladesh. The proposed hypotheses in this study can be described as follows.

$\mathrm{H}_{1}$ : There is a significant effect between motivation (the reason in choosing social entrepreneurship) and social entrepreneurship intention

$\mathrm{H}_{2}$ : There is a significant effect between society perceptions and social entrepreneurship intention

$\mathrm{H}_{3}$ : There is a significant effect between government obstacle and social entrepreneurship intention

$\mathrm{H}_{4}$ : There is a significant effect between barriers and social entrepreneurship intention

\section{Methods}

This study has been conducted on young graduates in Bangladesh both from public and private business schools or universities to understand their perception and tendency to become a social entrepreneurs. Survey data had been collected between September 2019 and December 2019. In total, 350 young graduates from 20 business schools/universities in Bangladesh did respond to the survey and all participants have been kept anonymous. In the first part, there were questions about the demographic profile of respondents with multiple choice questions about their gender, age, and qualification. There were also questions about if they did hear and understand the concept of social entrepreneurship and whether they wanted to have that career or not. However, there were also questions related to people's perception of social entrepreneurship, the motivational reasons choosing social entrepreneurship as their future career and the challenges also barrier associated with it. Secondary data was collected from relevant international published journal articles. The constructs in this study were formulated by using measurement scales adopted from prior studies to support the best opinion of the respondents regarding the perception of social entrepreneurship. Spearman correlation has been conducted to understand the relationship between motivational reasons, 
society perceptions, government obstacles, barriers, and social entrepreneurship intention among young business school graduates. Shen et al. (2018) added that spearman correlation is a reliable analysis to solve the problem which concerns nominal data and sequential data.

\section{Result and Discussion}

Our demographic profile shows that among 350 respondents, 54\% were male respondents while $46 \%$ of them were female. However, $21 \%$ of the respondents (which females were the majority) have not heard about social entrepreneurship. Therefore, it can be concluded that females have a lesser idea about the notion or conception of social entrepreneurship than males. Interestingly, $46 \%$ of the respondent perceived that people tend to become social entrepreneurs because they cannot get their desired job, while the rest of the respondents believe that being a social entrepreneur is easier than finding a job.

\section{Spearman's Correlation}

Table 1 shows that there is a significant relationship between motivation and social entrepreneurship intention among young business school graduates in Bangladesh. The probability value of this study was lower than 0.050 (0.000) which means $\mathrm{H}_{1}$ is accepted. This finding supports previous studies from Caringal-Go \& Hechanova (2018) who stated that motivation has a significant impact on social entrepreneurship. Table 1 also shows that there is a significant relationship between social perception and social entrepreneurship intention among young business school graduates in Bangladesh. The probability value of this study was lower than 0.050 (0.000) which means $\mathrm{H}_{2}$ is accepted. Maas \& Grieco (2017) stated that factors such as risk and uncertainty, a respectable career affect entrepreneurial behavior. These findings can be explained by our perceptual questions regarding motivational factors and society perception to become a social entrepreneur which shows that about $51 \%$ of the respondents perceived social entrepreneurship as a respectable career since this activity provides an opportunity for an individual to be more independent and engage with the community by creating a job for others (social value purpose). Contrarily, about $49 \%$ of the respondents (which females were about 30\%) do not prefer to become social entrepreneurs in the future since it seems too risky, has a lot of uncertainty, and seems like take the advantage of others difficulties or poverty. There is a slightly different level of acceptance between young business school graduates who perceived social entrepreneurship as a respectable and noble career choice with the others who perceived social entrepreneurship as a risky career path. 
Table 1. Hypotheses Testing

\begin{tabular}{|c|c|c|c|c|}
\hline Model & $\begin{array}{c}\text { The Correlation } \\
\text { Coefficient (r) }\end{array}$ & Criteria & Sig. Value & Decision \\
\hline \multicolumn{5}{|l|}{ Motivation -> Social } \\
\hline Entrepreneurship & 0.411 & Sig. Value $\leq 0.050$ & 0.000 & $\mathrm{H}_{1}$ Accepted \\
\hline \multicolumn{5}{|l|}{ Intention } \\
\hline \multicolumn{5}{|l|}{ Society Perception -> } \\
\hline $\begin{array}{l}\text { Social } \\
\text { Entrepreneurship }\end{array}$ & 0.590 & Sig. Value $\leq 0.050$ & 0.000 & $\mathrm{H}_{2}$ Accepted \\
\hline \multicolumn{5}{|l|}{ Intention } \\
\hline \multicolumn{5}{|l|}{ Government } \\
\hline $\begin{array}{l}\text { Obstacles -> Social } \\
\text { Entrepreneurship }\end{array}$ & 0.621 & Sig. Value $\leq 0.050$ & 0.000 & $\mathrm{H}_{3}$ Accepted \\
\hline \multicolumn{5}{|l|}{ Intention } \\
\hline \multicolumn{5}{|l|}{ Barriers -> Social } \\
\hline Entrepreneurship & 0.669 & Sig. Value $\leq 0.050$ & 0.000 & $\mathrm{H}_{4}$ Accepted \\
\hline Intention & & & & \\
\hline
\end{tabular}

The result of Spearman's Correlation (Table 1) shows that there is a significant relationship between government obstacles, barriers, and social entrepreneurship intention. The probability value of this study was lower than $0.050(0.000)$ which means $\mathrm{H}_{4}, \mathrm{H}_{5}$ is accepted. This finding support by Martín \& Martín \& Cuervo-Arango (2016) and Mueller et al. (2015) who stated that factors like excessive official formalities, rigid procedures, excessive administrative hurdles and unreasonable delay to obtain governments assistance are major obstacles in determining the intention on social entrepreneurship among the youth generation. Newey (2018) added that factors like difficulty in obtaining finance, government regulations, adequate business support, and tax regulations are perceived to be major barriers to social entrepreneurship. Moreover, the nature of uncertainty of social business, the greater financial risk, the lack of family support and practical details about starting a business also perceived as influential factors in determining the perception of social entrepreneurship among young graduates. Our perceptual questions regarding government obstacles and perceived barriers in doing social business show that about $44 \%$ of the respondents in this study agree with the statement that their family will not support and appreciate their decision 
to start a social business. However, $28 \%$ of the respondents are not sure about the procedure of starting a business. In addition to that, $60 \%$ of the respondents believe that social entrepreneurs have to go through excessive official formalities to get assistance for the startup business. Furthermore, 52\% of the respondents believe that procedures of getting government assistance are very rigid for social entrepreneurs while $43 \%$ of them believe that social entrepreneurs have to go through unreasonable due to lack of obtaining assistance from the government. Therefore, it can be concluded that the lack of involvement of the government in educating and supporting social business in Bangladesh affects young business school graduates (and their family) perception about social entrepreneurship development.

\section{Conclusion and Suggestion}

This study attempts to highlight the problems, prospects and motivating factors that encourage young business school graduates to engage in social entrepreneurship in Bangladesh. Our study revealed that the reason for choosing social entrepreneurship, government support obstacles, barriers or obstruction regarding entrepreneurship in general, and the way society perceives social entrepreneurship has a significant relationship on the perception of social entrepreneurship among young business school graduates in Bangladesh. Most of the respondents chose to participate in social entrepreneurship since it allows them to be independent while others believe that such activity can fulfill their social spirit by engaging with the community to create a job for others. They also perceived social entrepreneurship as a respectable and noble career in which they can also make money out of it.

Interestingly, although many young business school graduates perceived social entrepreneurship as a respectable and noble job, they also considered that job as a risky career, has a lot of uncertainty and seems like take the advantage of others difficulties or poverty. Moreover, they do not get family support and appreciation to do social business due to the reason that people tend to become social entrepreneurs because they cannot get their desired job. Finally, most of the respondents in this study do not possess a sound idea about the procedure of starting a social business. Many respondents believe that social entrepreneurs have to go through unreasonable hurdles to obtain assistance from the government. 
However, this study is limited to the factors influencing the perceptions of young business graduates. It does not include the perceptions of university graduates from every faculty or even vocational and high school graduates. Further comparative study of social entrepreneurship should extend the perspective in every young aged both from university, vocational, and high school graduates since this study found that there is slightly different of level acceptance between young business school graduates who perceived social entrepreneurship as a respectable and noble career choice with the others who perceived social entrepreneurship as a risky career path. Further study should also measure the dominance between internal and external factors of young graduates in choosing social entrepreneurship as their career.

\section{References}

Alvord, S. H., Brown, L. D., \& Letts, C. W. (2004). Social entrepreneurship and societal transformation. The Journal of Applied Behavioral Science, 40(3), 260-282. https://doi.org/10.1177/0021886304266847

Banodia, S. G., \& Dubey, N. (2017). Role of social entrepreneurs as social change agents: an insight. Research Journal of Management Sciences, 6(2), 19-22.

Baporikar, N. (2017). Boundaries and Challenges for Social Entrepreneurship. In Entrepreneurship: Concepts, Methodologies, Tools, and Applications (pp. 379-399). IGI Global. https://doi.org/10.4018/978-1-5225-1923-2.ch017

Blok, V., Hoffmans, L., \& Wubben, E. F. M. (2015). Stakeholder engagement for responsible innovation in the private sector: critical issues and management practices. Journal on Chain and Network Science, 15(2), 147-164. https://doi.org/10.3920/JCNS2015.x003

Caringal-Go, J. F., \& Hechanova, M. R. M. (2018). Motivational needs and intent to stay of social enterprise workers. Journal of Social Entrepreneurship, 9(3), 200-214. https://doi.org/10.1080/19420676.2018.1468352

Carvalho, J. M. S. (2017). Social innovation and entrepreneurship: The case of Porto region. In Entrepreneurship: Concepts, methodologies, tools, and applications (pp. 539-573). IGI Global. https://doi.org/10.4018/978-1-4666-9567-2.ch023

Catford, J. (1998). Social entrepreneurs are vital for health promotion--but they need supportive environments too. Health Promotion International, 13(2), 95-97. https://doi.org/10.1093/heapro/13.2.95 
Chandra, Y., \& Shang, L. (2017). Unpacking the biographical antecedents of the emergence of social enterprises: A Narrative perspective. VOLUNTAS: International Journal of Voluntary and Nonprofit Organizations, 28(6), 2498-2529. https://doi.org/10.1007/s11266-017-9860-2

Choi, N., \& Majumdar, S. (2014). Social entrepreneurship as an essentially contested concept: Opening a new avenue for systematic future research. Journal of Business Venturing, 29(3), 363-376. https://doi.org/10.1016/j.jbusvent.2013.05.001

Davis, S. M. (2002). Social entrepreneurship: Towards an entrepreneurial culture for social and economic development. Retrieved from https://papers.ssrn.com/sol3/papers.cfm?abstract_id=978868

De Bruin, A., \& Lewis, K. V. (2015). Traversing the terrain of context in social entrepreneurship. Journal of Social Entrepreneurship, 6(2), 127-136. https://doi.org/10.1080/19420676.2015.1038005

Dees, J., \& Anderson, B. (2003). For-profit social ventures. Social Entrepreneurship, 2(1), 126.

Dees, J. G., \& Elias, J. (1998). The challenges of combining social and commercial enterprise. Business Ethics Quarterly, 8(1), 165-178. https://doi.org/10.5840/10.2307/3857527

Drayton, W. (2006). Everyone a changemaker: Social entrepreneurship's ultimate goal. Innovations: Technology, Governance, Globalization, 1(1), 80-96. https://doi.org/10.1162/itgg.2006.1.1.80

Haugh, H. (2007). New strategies for a sustainable society: The growing contribution of social entrepreneurship. Business Ethics Quarterly, 17(4), 743-749. https://doi.org/10.5840/beq20071747

Lubberink, R., Blok, V., van Ophem, J., van der Velde, G., \& Omta, O. (2018). Innovation for society: Towards a typology of developing innovations by social entrepreneurs. Journal of Social Entrepreneurship, 9(1), 52-78. https://doi.org/10.1080/19420676.2017.1410212

Maas, K., \& Grieco, C. (2017). Distinguishing game changers from boastful charlatans: Which social enterprises measure their impact? Journal of Social Entrepreneurship, 
8(1), 110-128. https://doi.org/10.1080/19420676.2017.1304435

Martín, C. T., \& Cuervo-Arango, C. (2016). A Model for Social Entrepreneurship Education. In Handbook of Research on Social Entrepreneurship and Solidarity Economics (pp. 174-191). IGI Global.

Martin, R. L., \& Osberg, S. (2007). Social entrepreneurship: The case for definition. Stanford Social Innovation Review. Retrieved from http://www.ngobiz.org/picture/File/Social Enterpeuneur-The Case of Definition.pdf

Mueller, S., D’Intino, R. S., Walske, J., Ehrenhard, M. L., Newbert, S. L., Robinson, J. A., \& Senjem, J. C. (2015). What's holding back social entrepreneurship? Removing the impediments to theoretical advancement. Journal of Social Entrepreneurship, 6(3), 245256. https://doi.org/10.1080/19420676.2014.954259

Newey, L. R. (2018). 'Changing the system': Compensatory versus transformative social entrepreneurship. Journal of Social Entrepreneurship, 9(1), 13-30. https://doi.org/10.1080/19420676.2017.1408671

Newth, J., \& Woods, C. (2014). Resistance to social entrepreneurship: How context shapes innovation. Journal of Social Entrepreneurship, 5(2), 192-213. https://doi.org/10.1080/19420676.2014.889739

Pervez, T., Maritz, A., \& De Waal, A. (2013). Innovation and social entrepreneurship at the bottom of the pyramid - A conceptual framework. South African Journal of Economic and Management Sciences, 16(5), 54-66. https://doi.org/10.4102/sajems.v16i5.628

Phillips, W., Lee, H., Ghobadian, A., O’Regan, N., \& James, P. (2015). Social innovation and social entrepreneurship. Group \& Organization Management, 40(3), 428-461. https://doi.org/10.1177/1059601114560063

Popoviciu, I., \& Popoviciu, S. A. (2011). Social entrepreneurship, social enterprise and the principles of a community of practice. Revista de Cercetare Si Interventie Sociala, 33, 44. Retrieved from https://www.ceeol.com/search/article-detail?id=237163

Sassmannshausen, S. P., \& Volkmann, C. (2018). The scientometrics of social entrepreneurship and Its establishment as an academic field. Journal of Small Business Management, 56(2), 251-273. https://doi.org/10.1111/jsbm.12254

Seelos, C., \& Mair, J. (2005). Social entrepreneurship: Creating new business models to serve the poor. Business Horizons, 48(3), 241-246. 
https://doi.org/10.1016/j.bushor.2004.11.006

Shen, D., Li, X., \& Zhang, W. (2018). Baidu news information flow and return volatility: Evidence for the Sequential Information Arrival Hypothesis. Economic Modelling. https://doi.org/10.1016/j.econmod.2017.09.012

Sijabat, R. (2015). The role of social entrepreneurship in enabling economic opportunities for the poor: A synthesis of the literature and empirical works. International Journal of Business and Social Science, 6(11), 35-41.

Silva, A. C., \& Poza, C. (2016). A Review of the Social Entrepreneurship Phenomenon. In Handbook of Research on Social Entrepreneurship and Solidarity Economics (pp. 126). IGI Global. https://doi.org/https://doi.org/10.4018/978-1-5225-1923-2.ch001

Smith-Hunter, A. E. (2011). Toward a multidimensional model of social entrepreneurship: Definitions, clarifications, and theoretical perspectives. Journal of Business \& Economics Research (JBER), 6(6). https://doi.org/10.19030/jber.v6i6.2435

Stilgoe, J., Owen, R., \& Macnaghten, P. (2013). Developing a framework for responsible innovation. Research Policy, 42(9), 1568-1580. https://doi.org/10.1016/j.respol.2013.05.008

Thompson, J. L. (2002). The world of the social entrepreneur. International Journal of Public Sector Management, 15(5), 412-431. https://doi.org/10.1108/09513550210435746

Tiwari, P., Bhat, A. K., \& Tikoria, J. (2017a). An empirical analysis of the factors affecting social entrepreneurial intentions. Journal of Global Entrepreneurship Research, 7(1), 9. https://doi.org/10.1186/s40497-017-0067-1

Tiwari, P., Bhat, A. K., \& Tikoria, J. (2017b). The role of emotional intelligence and selfefficacy on social entrepreneurial attitudes and social entrepreneurial intentions. Journal of Social Entrepreneurship, $\quad 8(2), \quad 165-185$. https://doi.org/10.1080/19420676.2017.1371628

von Jacobi, N., Nicholls, A., \& Chiappero-Martinetti, E. (2017). Theorizing social innovation to address marginalization. Journal of Social Entrepreneurship, 8(3), 265-270. https://doi.org/10.1080/19420676.2017.1380340

Waddock, S., \& Steckler, E. (2016). Visionaries and wayfinders: Deliberate and emergent pathways to vision in social entrepreneurship. Journal of Business Ethics, 133(4), 719- 
734. https://doi.org/10.1007/s10551-014-2451-x

Weaver, R. L. (2018). Re-conceptualizing social value: applying the capability approach in social enterprise research. Journal of Social Entrepreneurship, 9(2), 79-93. https://doi.org/10.1080/19420676.2018.1430607

Wiklund, J., Davidsson, P., Audretsch, D. B., \& Karlsson, C. (2011). The future of entrepreneurship research. Entrepreneurship Theory and Practice, 35(1), 1-9. https://doi.org/10.1111/j.1540-6520.2010.00420.x 